\title{
Plasmid profiling as an epidemiological marker within Aeromonas salmonicida
}

\author{
B. Nielsen, J. E. Olsen, J. L. Larsen* \\ Department of Veterinary Microbiology, Royal Veterinary and Agricultural University, 13 Bulowsvej, \\ DK-1870 Frederiksberg C., Denmark
}

\begin{abstract}
A collection of 124 isolates of Aeromonas salmonicida ssp. salmonicida from Denmark, Norway, Scotland, and North America was plasmid profiled. All strains contained at least 1 large plasmid in the range of 60 to $150 \mathrm{~kb}$, and all strains possessed 2 low-molecular-weight plasmids of 5.2 and $5.4 \mathrm{~kb}$. Two additional low-molecular-weight plasmids of 5.6 and $6.4 \mathrm{~kb}$ were frequently encountered. A total of 23 different plasmids were demonstrated, 12 of them being found in more than one country. Forty different plasmid profiles were detected. Seven profiles, representing 75 strains (60\%), were demonstrated in isolates from more than one country. One profile, with 5 plasmids of $150,6.4,5.6,5.4$, and $5.2 \mathrm{~kb}$, proved to be the most common one among strains from North America (25\%), Denmark $(33 \%)$, and Norway $(50 \%)$, but it proved to be only the third most common one among Scottish strains $(10 \%)$. Plasmid profiling as an epidemiological typing method for Aeromonas salmonicida ssp. salmonicida was evaluated. The numerical index of discriminatory power $(D)$ was calculated, resulting in a relatively high $D$ value of 0.88 . However, the results of the present study suggest that plasmid profiling may be of limited value as an epidemiological marker within Aeromonas salmonicida ssp. salmonicida.
\end{abstract}

\section{INTRODUCTION}

Furunculosis, caused by the fish pathogenic bacterium Aeromonas salmonicida, is one of the major diseases among farmed salmonids in aquaculture. Now, nearly 100 yr after the first isolation of $A$. salmonicida by Emmerich \& Weibel 1894, this organism is found worldwide. Vaccination against furunculosis in fish farms does not seem to be effective in limiting the spread and outbreaks of the disease (Ellis 1988).

To understand and control the disease, it is desirable to develop typing systems that make detailed epidemiological studies possible. The use of traditional typing systems such as biotyping, serotyping, and resistotyping has been tried within Aeromonas salmonicida but without much success because of the homogeneous nature of this species (Austin \& Austin 1987). The only traditional typing system that has so far proven useful is phagetyping (Popoff 1971a, b, Rodgers et al. 1981) but this system has not been evaluated in large epidemiological investigations of $A$. salmonicida.

\footnotetext{
- Addressee for correspondence
}

Typing by plasmid profile analysis has proved to be an effective tool for studying the epidemiology of many pathogenic bacteria (Farrar 1983). Reports on the plasmid content of Aeromonas salmonicida have been published (Ishiguro et al. 1981, Toranzo et al. 1983, Hackett et al. 1984, Bast et al. 1988, Belland \& Trust 1989), but generally the number of strains investigated has been very small. In addition, different plasmid purification methods have been used, which makes a direct comparison of the results difficult.

In this report, we present the results from plasmid profiling of strains of Aeromonas salmonicida from Denmark, Norway, Scotland, and North America with the aim of evaluating this method as an epidemiological marker system for this bacterium.

\section{MATERIALS AND METHODS}

Bacterial strains and growth conditions. A collection of 124 strains of Aeromonas salmonicida ssp. salmonicida from Denmark, Norway, Scotland and North America was investigated. The strains are listed in 
Table 1. None of the strains have been used for any other published study. The Danish strains were provided by $\mathrm{Dr}$ I. Dalsgaard, Danish Institute for Fisheries and Marine Research, Fish Disease Laboratory, Royal Veterinary and Agricultural University, Copenhagen, Denmark. The Norwegian strains were supplied by Dr E. Myhr, National Veterinary Institute, Oslo, Norway. The Scottish strains were received from Dr T. Hastings, The Scottish Office Agriculture and Fisheries Department, Marine Laboratory, Aberdeen, Scotland. Finally, strains from North America were received from Dr G. Olivier, Dept of Fisheries \& Oceans, Halifax, Canada. All strains were isolated from diseased salmonids as mentioned in Table 1. One reference strain, Aeromonas salmonicida ssp. salmonicida NCMB 1102, was also examined.

The strains were grown on brain heart infusion (BHI) agar (Difco). After $48 \mathrm{~h}$ incubation at $20^{\circ} \mathrm{C}, 5$ to 8 colonies were harvested, mixed in 1 Eppendorf tube and used for plasmid profiling.

Plasmid profiling. Plasmid isolations were carried out using the method of Kado \& Liu (1981), modified by incubating the cells at elevated $\mathrm{pH}(12.75)$ for $20 \mathrm{~min}$ at $56{ }^{\circ} \mathrm{C}$ during the lysis step. DNA samples $(15 \mu \mathrm{l})$ were subjected to electrophoresis in 2 different gels: a $1 \%$ agarose gel [Litex LSL agarose in Tris acetate EDTA buffer (TAE) (Maniatis et al. 1982)] was used for the separation of small plasmids, and a $0.7 \%$ agarose gel in TAE buffer was used for the separation of large plasmids. Small plasmids were separated at $30 \mathrm{~V}$ for $17 \mathrm{~h}$; large plasmids were separated at $80 \mathrm{~V}$ for $3 \mathrm{~h}$. Plasmids were visualised as previously described (Olsen et al. 1990).

Statistics. Numerical index of discriminatory power (D) was calculated as recommended by Hunter \& Gaston (1988) as:

$$
D=1-\frac{1}{N(N-1)} \sum_{j=1}^{s} n_{j}\left(n_{j}-1\right)
$$

where $N$ is the total number of strains in the sample population, $s$ is the total number of profiles, and $n$ is the niumber of strains belonging to the $j$ th profile. The discriminatory power is an expression of the probability that 2 strains chosen at random from a population of unrelated strains can be distinguished by the typing system. Thus, a $D$ value of 1.0 would indicate that a typing method was able to distinguish all members of a population of unrelated strains from all other members of that population. Typeability was defined as the percentage of strains that could be plasmid profiled using the Kado \& Liu method (1981). Reproducibility was defined as the percentage of strains that gave the same result on repeated testing.

Table 1. Source and year of isolation of the examined Aeromonas salmonicida from North America, Denmark, Norway, and Scotland. Values indicate no. of strains per host species

\begin{tabular}{|c|c|c|c|c|c|c|c|c|c|c|c|}
\hline \multirow[t]{2}{*}{ Source and host } & \multicolumn{11}{|c|}{ Year of isolation } \\
\hline & 1970 & 1980 & 1982 & 1983 & 1984 & 1985 & 1986 & 1987 & 1988 & 1989 & 1990 \\
\hline \multicolumn{12}{|l|}{ North America ${ }^{\dot{a}}$} \\
\hline Salmo salar & & 1 & & & 1 & & 1 & & & 1 & 6 \\
\hline Salmo trutta & & & 1 & 1 & & & 1 & & & & \\
\hline Salvelinus fontinalis & & & & & & 1 & & & & 1 & \\
\hline Oncorhynchus mykiss & & & & & & 1 & & & & 1 & \\
\hline Oncorhynchus tsawytscha & 1 & & & & & & 1 & & & & \\
\hline \multicolumn{12}{|l|}{ Denmark $^{b}$} \\
\hline Oncorhynchus mykiss & & & 8 & 7 & 8 & 8 & 4 & 4 & 2 & & \\
\hline Salmo trutta & & & & 1 & 2 & 1 & 2 & 1 & 3 & & \\
\hline Salvelinus fontinalis & & & & 2 & 1 & & & 1 & & & \\
\hline Salmo salar & & & & 1 & & 1 & & & & & \\
\hline \multicolumn{12}{|l|}{ Norwayc } \\
\hline Salmo salar & & & & & & & & & & & 24 \\
\hline Oncorhynchus mykiss & & & & & & & & & & & 4 \\
\hline \multicolumn{12}{|l|}{ Scolland $^{d}$} \\
\hline Salmo salar & & & & & & & & & & & 20 \\
\hline
\end{tabular}




\section{RESULTS}

\section{Plasmid sizes}

All strains of Aeromonas salmonicida examined showed multiple bands of plasmid DNA. The strains had at least 1 large plasmid in the range of 60 to 150 $\mathrm{kb}$, and all strains possessed 2 low-molecular-weight plasmids of 5.2 and $5.4 \mathrm{~kb}$. In addition, 2 low-molecular-weight plasmids of 5.6 and $6.4 \mathrm{~kb}$ were frequently encountered.

Table 2 lists the total number of different plasmids demonstrated in the strains. Estimates of plasmid size varied somewhat between experiments. This variation in estimates of molecular size increased with the size of the plasmid. The gel to gel variation in the estimated size of a particular plasmid is expressed as a size range for each particular plasmid, as shown in Table 2

Twelve of the 23 different plasmids were found in more than one country. Eleven plasmids, of which a $150 \mathrm{~kb}$ plasmid was the most frequently observed high-molecular-weight plasmid $158 \%$ of the North American strains), were detected among the North American strains. Four of the small plasmids were found to be widespread, occurring in most of the isolates regardless of geographical origin. The plasmids of $6.4,5.6,5.4$, and $5.2 \mathrm{~kb}$ were detected in $78.3,91$, 100 , and $100 \%$ of isolates respectively.

Table 2. Aeromonas salmonicida. Plasmid sizes ( $\pm \mathrm{SE}$ ) observed among 124 clinical isolates. Total no. of strains: Denmark (D) 57. Norway (N) 28, North America (NA) 19, Scotland (S) 20

\begin{tabular}{|c|c|c|}
\hline Size $(k b)$ & No. of strains & $\%$ \\
\hline $170 \pm 15$ & $1 \mathrm{D}$ & 0.8 \\
\hline $150 \pm 10$ & $38 \mathrm{D}, 18 \mathrm{~N}, 11 \mathrm{NA}, 6 \mathrm{~S}$ & 58.4 \\
\hline $130 \pm 10$ & $5 \mathrm{D}, 4 \mathrm{NA}$ & 7.2 \\
\hline $110 \pm 9$ & $4 \mathrm{NA}$ & 3.2 \\
\hline $100 \pm 9$ & $3 \mathrm{D}, 10 \mathrm{~N}, 2 \mathrm{NA}, 4 \mathrm{~S}$ & 15.0 \\
\hline $95 \pm 8$ & $1 \mathrm{D}$ & 0.8 \\
\hline $90 \pm 8$ & $2 \mathrm{D}$ & 1.6 \\
\hline $85 \pm 7$ & $9 \mathrm{D}, 1 \mathrm{~S}$ & 8.0 \\
\hline $75 \pm 7$ & $4 \mathrm{NA}, 6 \mathrm{~S}$ & 8.1 \\
\hline $70 \pm 6$ & $3 \mathrm{D}, 1 \mathrm{NA}$ & 3.2 \\
\hline $63 \pm 5$ & $1 \mathrm{D}, 5 \mathrm{~S}$ & 4.8 \\
\hline $60 \pm 5$ & $2 \mathrm{D}$ & 1.6 \\
\hline $45 \pm 4$ & $1 \mathrm{D}$ & 0.8 \\
\hline $35 \pm 3$ & $1 \mathrm{~S}$ & 0.8 \\
\hline $21 \pm 2$ & $1 \mathrm{~N}$ & 0.8 \\
\hline $13 \pm 2$ & $2 \mathrm{NA}$ & 1.6 \\
\hline $10.5 \pm 0.5$ & $1 \mathrm{~S}$ & 0.8 \\
\hline $8.5 \pm 0.2$ & $5 \mathrm{~N}, 8 \mathrm{~S}$ & 10.4 \\
\hline $8.0 \pm 0.2$ & $1 \mathrm{~S}$ & 0.8 \\
\hline $6.4 \pm 0.1$ & $43 \mathrm{D}, 24 \mathrm{~N}, 18 \mathrm{NA}, 12 \mathrm{~S}$ & 78.3 \\
\hline $5.6 \pm 0.1$ & $49 \mathrm{D}, 28 \mathrm{~N}, 18 \mathrm{NA}, 18 \mathrm{~S}$ & 91.0 \\
\hline $5.4 \pm 0.1$ & $57 \mathrm{D}, 28 \mathrm{~N}, 19 \mathrm{NA}, 20 \mathrm{~S}$ & 100.0 \\
\hline $5.2 \pm 0.1$ & $57 \mathrm{D}, 28 \mathrm{~N}, 19 \mathrm{NA}, 20 \mathrm{~S}$ & 100.0 \\
\hline
\end{tabular}

Fifteen different plasmids were detected among the Danish strains. The most common large plasmid, 150 $\mathrm{kb}$, was observed in $68 \%$ of the strains. The following small plasmids were also commonly present: $6.4 \mathrm{~kb}$ $(75 \%), 5.6 \mathrm{~kb}(86 \%), 5.4 \mathrm{~kb}(100 \%)$, and $5.2 \mathrm{~kb}$ $(100 \%)$.

Eight different plasmids were detected among the Norwegian strains, and 5 of them were the most commonly encountered: $150 \mathrm{~kb}(64 \%), 6.4 \mathrm{~kb}(96 \%), 5.6$ $\mathrm{kb}(100 \%), 5.4 \mathrm{~kb}(100 \%)$, and $5.2 \mathrm{~kb}(100 \%)$.

Scottish strains showed considerable diversity with respect to plasmid content. A total of 13 different plasmids were detected in the 20 strains (see Table 2 for details).

A number of plasmids were restricted to specific geographical areas (Table 3). Danish strains harboured 5 plasmids exclusively found in Denmark $(170,95,90$, $60,45 \mathrm{~kb}$ ), while Norwegian isolates carried 1 (21 kb), Scottish isolates $3(35,10.5,8.0 \mathrm{~kb})$, and North American isolates $2(110,13 \mathrm{~kb})$ plasmids that were unique to Norway, Scotland, and North America, respectively.

\section{Plasmid profiles}

As seen from Table 4 , a total of 40 different plasmid profiles were detected in the 125 strains investigated. Seven profiles, representing 75 strains (60\%), were demonstrated in isolates from more than one country. One profile, with 5 plasmids of $150,6.4,5.6,5.4$, and $5.2 \mathrm{~kb}$, was the most commonly demonstrated one among strains from North America (25\%), Denmark (32\%), and Norway (50\%). This profile was the third most commonly demonstrated one among strains from Scotland $(11 \%)$. The ratios of number of strains to number of profiles from each country were: Denmark: 2.7; Norway: 4.7; Scotland: 1.5; and North America: 1.9 .

Reference strain NCMB 1102 harboured plasmids at $150,6.4,5.65 .4$, and $5.2 \mathrm{~kb}$, thereby belonging to pro-

Table 3. Aeromonas salmonicida. Bacterial plasmids detected exclusively in certain countries. no: number of strains carrying the specified plasmid in the given country. Number of strains examined: Denmark, 57, Norway, 28, North America, 19; Scotland, 20. Molecular size is in kb

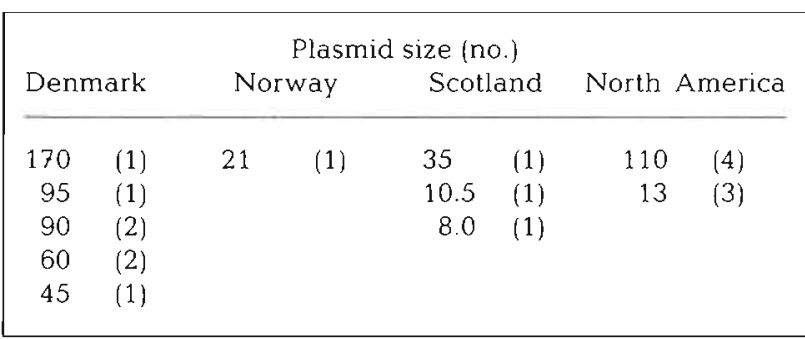


Table 4. Aeromonas salmonicida. Plasmid profiles detected in 124 strains. Total no. of strains: Denmark (D) 57, Norway (N) 28, North America (NA) 19, Scotland (S) 20

\begin{tabular}{|c|c|c|c|c|c|c|c|c|c|c|c|}
\hline \multirow{2}{*}{$\begin{array}{c}\text { Profile } \\
\text { no. } \\
1\end{array}$} & \multirow{2}{*}{$\begin{array}{l}\begin{array}{l}\text { No. of strains } \\
\text { per country }\end{array} \\
1 \mathrm{D}\end{array}$} & \multicolumn{10}{|c|}{ Plasmid size $(\mathrm{kb})$} \\
\hline & & 170 & & & & & & 6.4 & 5.6 & 5.4 & 5.2 \\
\hline 2 & $18 \mathrm{D}, 14 \mathrm{~N}, 5 \mathrm{NA}, 2 \mathrm{~S}$ & 150 & & & & & & 6.4 & 5.6 & 5.4 & 5.2 \\
\hline 3 & $7 \mathrm{D}, 1 \mathrm{~N}$ & 150 & & & & & & & 5.6 & 5.4 & 5.2 \\
\hline 4 & $4 \mathrm{D}$ & 150 & & & & & & & & 5.4 & 5.2 \\
\hline 5 & $2 D$ & 150 & & & & & & 6.4 & & 5.4 & 5.2 \\
\hline 6 & $1 \mathrm{NA}$ & 150 & 110 & & & & & 6.4 & 5.6 & 5.4 & 5.2 \\
\hline 7 & $1 \mathrm{NA}$ & 150 & 100 & & & & & 6.4 & 5.6 & 5.4 & 5.2 \\
\hline 8 & $3 \mathrm{D}$ & 150 & 85 & & & & & 6.4 & 5.6 & 5.4 & 5.2 \\
\hline 9 & $1 \mathrm{D}$ & 150 & 85 & & & & & 6.4 & & 5.4 & 5.2 \\
\hline 10 & $1 \mathrm{~S}$ & 150 & 85 & & & & 8.5 & & 5.6 & 5.4 & 5.2 \\
\hline 11 & $2 \mathrm{NA}$ & 150 & 75 & & & & & 6.4 & 5.6 & 5.4 & 5.2 \\
\hline 12 & $1 D$ & 150 & 70 & & & & & 6.4 & 5.6 & 5.4 & 5.2 \\
\hline 13 & $1 D$ & 150 & 60 & & & & & 6.4 & 5.6 & 5.4 & 5.2 \\
\hline 14 & $1 D$ & 150 & 60 & & & & & 6.4 & & 5.4 & 5.2 \\
\hline 15 & $1 N$ & 150 & & & & 21 & & 6.4 & 5.6 & 5.4 & 5.2 \\
\hline 16 & $2 \mathrm{NA}$ & 150 & & & & 13 & & 6.4 & 5.6 & 5.4 & 5.2 \\
\hline 17 & $2 \mathrm{~N}, 3 \mathrm{~S}$ & 150 & & & & & 8.5 & & 5.6 & 5.4 & 5.2 \\
\hline 18 & $2 \mathrm{D}, 3 \mathrm{NA}$ & 130 & & & & & & 6.4 & 5.6 & 5.4 & 5.2 \\
\hline 19 & $2 \mathrm{D}$ & 130 & & & & & & & 5.6 & 5.4 & 5.2 \\
\hline 20 & $1 \mathrm{NA}$ & 130 & 100 & & & & & & & 5.4 & 5.2 \\
\hline 21 & $1 \mathrm{D}$ & 130 & 8 & & & & & 6.4 & 5.6 & 5.4 & 5.2 \\
\hline 22 & $2 \mathrm{NA}$ & 110 & & & & & & 6.4 & 5.6 & 5.4 & 5.2 \\
\hline 23 & $1 \mathrm{NA}$ & 110 & 75 & & & & & 6.4 & 5.6 & 5.4 & 5.2 \\
\hline 24 & $3 \mathrm{D}, 8 \mathrm{~N}, 1 \mathrm{~S}$ & 100 & & & & & & 6.4 & 5.6 & 5.4 & 5.2 \\
\hline 25 & $1 \mathrm{~S}$ & 100 & & & & & & 6.4 & & 5.4 & 5.2 \\
\hline 26 & $2 \mathrm{~N}, 1 \mathrm{~S}$ & 100 & & & & & 8.5 & & 5.6 & 5.4 & 5.2 \\
\hline 27 & $1 \mathrm{~S}$ & 100 & & & & & 8.0 & 6.4 & & 5.4 & 5.2 \\
\hline 28 & $1 \mathrm{D}$ & 95 & & 45 & & & & 6.4 & 5.6 & 5.4 & 5.2 \\
\hline 29 & $1 \mathrm{D}$ & 90 & & & & & & 6.4 & 5.6 & 5.4 & 5.2 \\
\hline 30 & $1 \mathrm{D}$ & 90 & & & & & & & 5.6 & 5.4 & 5.2 \\
\hline 31 & $3 \mathrm{D}$ & 85 & & & & & & 6.4 & 5.6 & 5.4 & 5.2 \\
\hline 32 & $1 \mathrm{D}$ & 85 & & & & & & & 5.6 & 5.4 & 5.2 \\
\hline 33 & $4 \mathrm{~S}$ & 75 & & & & & & 6.4 & 5.6 & 5.4 & 5.2 \\
\hline 34 & $1 \mathrm{NA}$ & 75 & & 70 & & & & 6.4 & 5.6 & 5.4 & 5.2 \\
\hline 35 & $1 \mathrm{~S}$ & 75 & & 63 & & & 8.5 & & 5.6 & 5.4 & 5.2 \\
\hline 36 & $1 \mathrm{~S}$ & 75 & & 63 & & & 10.5 & 6.4 & 5.6 & 5.4 & 5.2 \\
\hline 37 & $2 \mathrm{D}$ & 70 & & & & & & 6.4 & 5.6 & 5.4 & 5.2 \\
\hline 38 & $1 \mathrm{D}, 2 \mathrm{~S}$ & & & 63 & & & & 6.4 & 5.6 & 5.4 & 5.2 \\
\hline 39 & $1 \mathrm{~S}$ & & & 63 & & & 8.5 & & 5.6 & 5.4 & 5.2 \\
\hline 40 & $1 \mathrm{~S}$ & & & & 35 & & 8.5 & & 5.6 & 5.4 & 5.2 \\
\hline
\end{tabular}

file no. 2 (Table 4), the most commonly observed profile in the present study.

\section{Epidemiological test characteristics}

The numerical index of discriminatory power (D) was calculated for plasmid profiling as a typing method. The 125 strains were distributed in 40 plasmid profiles resulting in a $D$-value of 0.88 . All strains showed multiple plasmid bands corresponding to a typeability of $100 \%$. The reproducibility of the Kado \&
Liu (1981) method was found to be more than $95 \%$ on retesting of all 125 strains.

Plasmid profile stability was evaluated on the 57 Danish strains over a period of nearly 3 yr using at least 10 independent plasmid profilings. Additionally, the rest of the strain collection was evaluated over a period of $1 \mathrm{yr}$ using at least 5 independent plasmid profilings. The plasmid stability was very high, none of the strains losing any of their plasmids. However, from time to time the yield of large plasmid DNA (130 to $170 \mathrm{~kb})$ was so low that this plasmid DNA was invisible by ethidium bromide staining. 

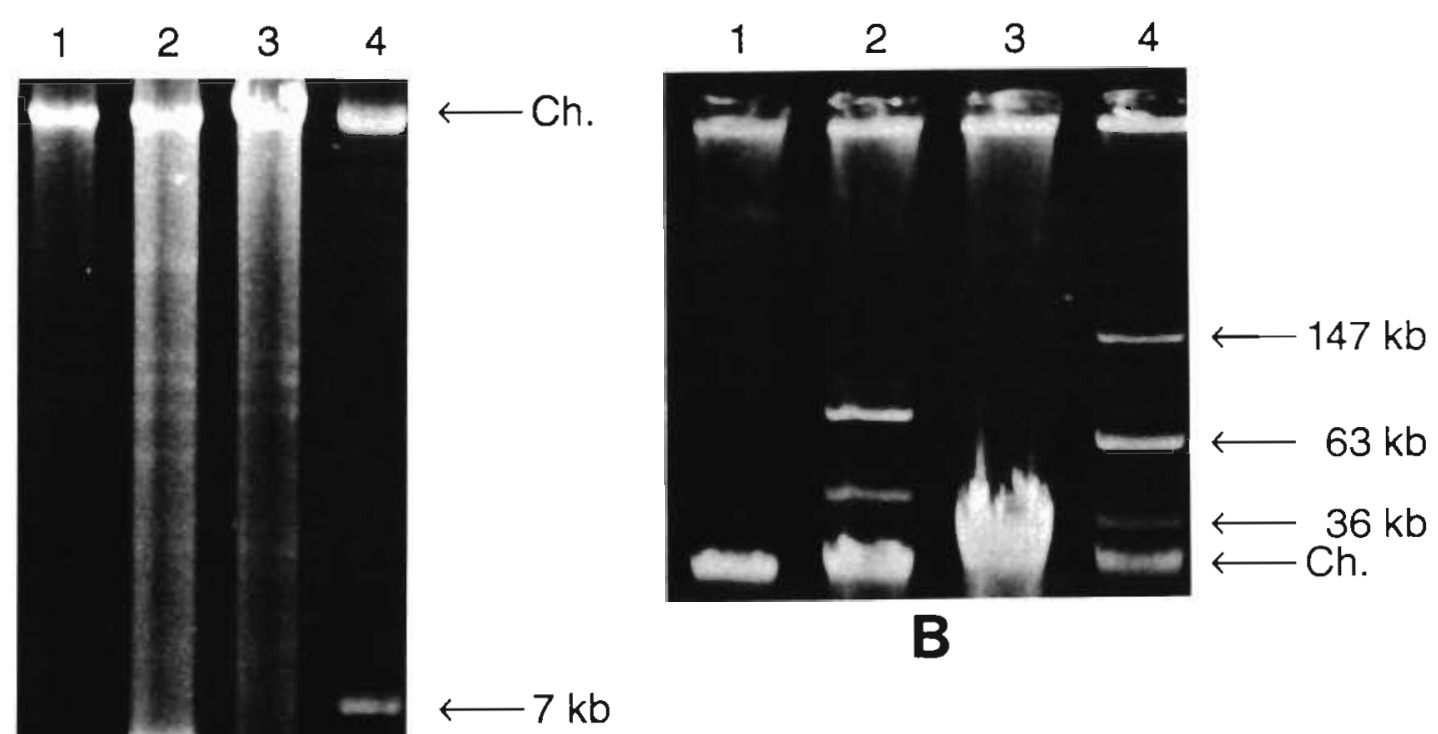

Fig. 1. Aeromonas salmonicida (A.s.) plasmids. Chromosomal band is indicated by Ch. (A) Separation of small plasmids using a $1.0 \%$ agarose gel; running conditions: $17 \mathrm{~h}$ at $30 \mathrm{~V}$. The weak bands between the chromosomal band and the pronounced small plasmids are open circle (OC) forms of the small plasmids. Lane 1: A.s. with plasmids of 5.2 and $5.4 \mathrm{~kb}$. Lane 2: A.s. with plasmids of 5.2, 5.4, 5.6 and $6.4 \mathrm{~kb}$. Lane 3: A.s. with plasmids of 5.2, 5.4 and $5.6 \mathrm{~kb}$. Lane 4: Marker Escherichia coli 39R 861 with plasmid of $7 \mathrm{~kb}$. (B) Separation of large plasmids using a $0.7 \%$ agarose gel; running conditions: $3 \mathrm{~h}$ at $80 \mathrm{v}$. Lane 1: A.s. with plasmid of $150 \mathrm{~kb}$. Lane 2: A.s. with plasmids of 45 and $95 \mathrm{~kb}$. Lane 3: A.s. with plasmid of $150 \mathrm{~kb}$. Lane 4: Marker E. coll $39 \mathrm{R} 861$ with plasmids of 36,63 , and $147 \mathrm{~kb}$

\section{Method of plasmid isolation}

The yield of purified plasmid DNA showed a clear molecular size dependence. Small plasmids were always purified in large quantities, and satisfactory separation could only be achieved when a relatively small amount of a sample $(15 \mu \mathrm{l})$ was run overnight in a $1 \%$ agarose gel. In contrast, large plasmids were always purified in very small quantities. A satisfactory separation of the large plasmids could be achieved by running a sample of $30 \mu \mathrm{l}$ for $3 \mathrm{~h}$ in a $0.7 \%$ agarose gel. Fig. 1 shows examples of plasmid separation on $1 \%$ and $0.7 \%$ agarose gels and illustrates the migration pattern of 3 commonly observed plasmid profiles among Aeromonas salmonicida ssp. salmonicida.

\section{DISCUSSION}

A number of different plasmid purification methods have been used for Aeromonas salmonicida ssp. salmonicida, some of them giving different results. Toranzo et al. (1983) examined 4 previously described plasmid DNA purification methods, i.e. those of Newland et al. (1980), Holmes \& Quigley (1981), Kado \& Liu (1981), and Portnoy et al. (1981). Optimal results were achieved with the method of Kado \& Liu (1981); it gave a good yield of both low- and high-molecularweight plasmids.

Additional reports (Hackett et al. 1984, Bast et al. 1988, Belland \& Trust 1989) have confirmed that reproducible results can be obtained with the rapid method of Kado \& Liu (1981). In the present study, we found that the optimal yield of plasmid DNA was achieved at a pH of 12.75. The original pH in the Kado \& Liu (1981) method was 12.54 . The results of the present study indicate that minor adjustments might be important when the method is used for species of bacteria not belonging to the Enterobacteriaceae.

Bast et al. (1988) examined 35 Aeromonas salmonicida ssp. salmonicida strains isolated in Canada and found a highly conserved group of small plasmids of $4.9,5.2,5.4$ and $6.3 \mathrm{~kb}$ to be present. This group of plasmids was also reported by Toranzo et al. (1983), Hackett et al. (1984), and Belland \& Trust (1989), all using the method of Kado \& Liu (1981). McCormick et al. (1990) recognized 4 plasmids of $3.9,5.2,5.8$, and 7.4 $\mathrm{kb}$ using the method of Portnoy et al. (1981).

In the present investigation, we demonstrated that all 125 strains of Aeromonas salmonicida ssp. salmonicida tested contained more than 1 band of plasmid DNA, and that all strains possessed 2 low-molecularweight plasmids of $5.2 \mathrm{~kb}$ (pAs1) and $5.4 \mathrm{~kb}$ (pAs2). Two other low-molecular-weight plasmids of $5.6 \mathrm{~kb}$ 
(pAs3) and $6.4 \mathrm{~kb}$ (pAs4) were also frequently encoutered. The designations pAs 1 to pAs 4 for the 4 small plasmids were proposed by Belland \& Trust (1989). These abbreviations are used in the present study, since, despite minor discrepancies in size estimation, we assume that we were dealing with this group of plasmids.

The present investigation is the first to demonstrate strains without the third (pAs3) plasmid of $5.6 \mathrm{~kb}$. This plasmid was lacking in $8(14 \%)$ of the Danish strains, in $2(10 \%)$ of the Scottish strains, and in $1(5 \%)$ of the North American strains. Strains lacking this plasmid were not observed among Norwegian isolates.

Scottish strains often (40\%) possessed an $8.5 \mathrm{~kb}$ plasmid substituting for the $6.4 \mathrm{~kb}$ plasmid and this phenomenon was also observed in 4 (14\%) Norwegian strains. Each time the $8.5 \mathrm{~kb}$ plasmid was detected, the $6.4 \mathrm{~kb}$ plasmid was lacking, indicating either that the 2 plasmids belong to the same incompatibility group, or that the $8.5 \mathrm{~kb}$ plasmid might be the $6.4 \mathrm{~kb}$ plasmid with an insert. The $8.5 \mathrm{~kb}$ plasmid was only detected in strains from Scotland and Norway. This observation may suggest that farmed Norwegian salmon have been infected by salmon imported from Scotland, or vice versa.

The occurrence of large plasmids in Aeromonas salmonicida ssp. salmonicida has been reported by Ishiguro et al. (1981), and Toranzo et al. (1983), Hackett et al. (1984), Bast et al. (1988), Belland \& Trust (1989). The results of those publications dealing with relatively small numbers of strains are confirmed by our findings which showed all of the strains to contain large $(50$ to $170 \mathrm{~kb}$ ) plasmids. However, none of the listed studies reported that plasmid size varied from gel to gel. Direct comparison with the listed studies is therefore not possible.

Belland \& Trust (1989) examined the genetic relationships among the large plasmids using digestion with restriction enzymes and showed that the plasmids displayed considerable genetic relatedness. Additionally, using the restriction enzyme BamH 1 on the total plasmid content, Belland \& Trust (1989) showed that Aeromonas salmonicida ssp. salmonicida strains had identical or very similar restriction digestion fingerprint patterns, supporting the hypothesis that A. salmonicida ssp. salmonicida is a very homogeneous species.

In our study, there was no correlation between fish species and plasmid content. Similarly, no trends in distribution of profiles were observed in relation to year of isolation of the strains (data nat shown). The question is then: Can plasmid profiling be used as an epidemiological marker within Aeromonas salmonicida ssp. salmonicida? Certainly, the approach appeared to have potential. Certain variations in plasmid contents were demonstrated in the study, certain plasmids being detected in only certain areas (Table 3 ).

In addition, the system had the desirable features of high stability, high typeability, high reproducibility, and effective discrimination on the subspecies level (Hunter \& Gaston 1988, Hunter 1990). Unfortunately, despite all of these favourable features our results indicate that plasmid profiling in general is a method with limited value as an epidemiological marker within Aeromonas salmonicida ssp. salmonicida. Too many plasmid profiles were shared by all 4 areas, and the unique plasmid profiles were rather rare, e.g. only 1 unique profile was found in Norway and it represented only $1(3.6 \%)$ of the isolates from that country. However, compared to traditional typing methods such as biotyping (few iypes), serviypiny (i i lype), and i esis. totyping (few types), plasmid profiling (with at least up to 40 profiles) may nevertheless be a useful epidemiological tool in certain geographical areas. For example, the low number of country-specific profiles found in Norway suggests that $A$. salmonicida ssp. salmonicida is a recently introduced organism in the area, and that the organism has been introduced from a limited number of sources.

Acknowledgements. This study was supported by the Danish Agricultural and Veterinary Research Council no. 13-442-44, and by the OECD Co-operative Research Project on Biological Resource Management. The skilled technical assistance of Sussi Kristoffersen is very much appreciated.

\section{LITERATURE CITED}

Austin, B., Austin, D. A. (1987). Bacterial fish pathogens: disease in farmed and wild fish. Ellis Horwood Ltd, Chichester

Bast, L., Daly, J. G., DeGrandis, S. A., Stevenson, R. M. W. (1988). Evaluation of profiles of Aeromonas salmonicida as epidemiological markers of furunculosis in fish. J. Fish Dis. 11: 133-145

Belland, R. J., Trust, T. J.(1989). Aeromonas salmonicida plasmids: plasmid-directed synthesis of proteins in vitro and in Escherichia coli minicells. J. gen. Microbiol. 135: 513-524

Ellis, A. E. (1988). Fish vaccination. Academic Press, New York

Emmmerich, R., Weibel, E. (1894\}. Über eine durch Bakterien erzeugte Seuche unter den Forellen. Arch. Hyg. Bakteriol. 21: $1-21$

Farrar, W. E. J. (1983). Molecular analysis of plasmids in epidemiological investigation. J. infect. Dis. 148: 1-6

Hackett, J L., Lynch, W. H., Paterson, W. D.. Coombs, D. H. (1984). Extracellular protease, extracellular haemolysin, and virulence in Aeromonas salmonicida. Can. J. Fish. Aquat. Sci. 41: 1354-1360

Holmes, D., Quigley, M. (1981). A rapid boiling method for the preparation of bacterial plasmids. Anal. Biochem. 114: 193-197

Hunter, P. R. (1990). Reproducibility and indices of discriminatory power of microbial typing methods. J. clin. Microbiol. 28: 1903-1905

Hunter, P. R., Gaston, M. A. (1988). Numerical index of the 
discriminatory ability of typing systems: an application of Simpson's index of diversity. J. clin. Microbiol. 26: 2465-2466

Ishiguro, E., Kay, W. W., Ainsworth, T., Chamberlain, J. B. Austin, R. A., Buckley, J. T., Trust, T. J. (1981). Loss of virulence during culture of Aeromonas salmonicida at high temperature. J. Bacteriol. 148: 333-340

Kado, C. I., Liu, S. T. (1981). Rapid procedure for detection and isolation of large and small plasmids. J. Bacteriol. 145: $1365-1373$

Maniatis, T., Fritsch, E. F., Sambrook, J. (1982). Molecular cloning: a laboratory manual Cold Spring Harbor Laboratory, Cold Spring Harbor, NY

McCormick, W. A., Stevenson, R. M. W., Macinnes, J. I. (1990). Restriction endonuclease fingerprinting analysis of Canadian isolates of Aeromonas salmonicida. Can. J. Microbiol. 36: 24-32

Newland, J. W., McNicol, L. A., Voll, M. J., Colwell, R. R. (1980). Rapid screening for plasmids in environmental isolates of Vibrio cholerae by an in the well lysis technique using horizontal gel electrophoresis. Plasmid 3:238

Responsible Subject Editor: T. Evelyn, Nanaimo, B.C., Canada
Olsen, J. E., Baggesen, D. L., Nielsen, B. B., Larsen, H. E. (1990). The prevalence of plasmids in Danish bovine and human isolates of Salmonella dublin. APMIS 98: 735-740 Popoff, M. (1971a). Etude sur les Aeromonas salmonicida. II. Caractérisation des bactèriophages actifs sur les 'Aeromonas salmonicida' et lysotypie. Ann. Rech vet. 2 : 35-45

Popoff, M. (1971b). Interét diagnostigue d'un bacteriophage specifique des Aeromonas salmonicida. Ann. Rech. vet. 2: $137-139$

Portnoy, D. A., Moseley, J. H., Falkow, S. (1981). Characterization of plasmids and plasmid-associated determinants of Yersinia enterocolitica pathogenesis. Infect. Immun. 31: 775-782

Rodgers, C. J., Pringle, J. H., McCarthy, D. H., Austin, D. (1981). Quantitative and qualitative studies of Aeromonas salmonicida bacteriophage. J. gen. Microbiol. 125: $335-345$

Toranzo, A., Barja, J. L., Colwell, R. R., Hetrick, F. M. (1983). Characterization of plasmids in bacterial fish pathogens. Infect. Immun. 39: 185-19

Manuscript first received: May 11, 1992

Revised version accepted: September 23, 1992 